\title{
Efficacy of trabectedin in advanced soft tissue sarcoma: beyond lipo- and leiomyosarcoma [Corrigendum]
}

De Sanctis R, Marrari A, Marchetti S, et al. Drug Des Devel

Ther. 2015;9:5785-5791.

The authors note that on page 5787, Figure 1 , the bottom bar

is missing the label "liposarcoma".

\section{Publish your work in this journal}

Drug Design, Development and Therapy is an international, peerreviewed open-access journal that spans the spectrum of drug design and development through to clinical applications. Clinical outcomes, patient safety, and programs for the development and effective, safe, and sustained use of medicines are a feature of the journal, which has also been accepted for indexing on PubMed Central. The manuscript management system is completely online and includes a very quick and fair peer-review system, which is all easy to use. Visit http://www.dovepress.com/testimonials.php to read real quotes from published authors.

Submit your manuscript here: http://www.dovepress.com/drug-design-development-and-therapy-journal 